\title{
Investigation of Minimum Protein Percentage Required for Optimum Growth of Siamese Fighter Fish, Betta Splendens (Regan, 1950) in Juvenile Stage
}

\author{
Chathurani S.H.U., Rajapakshe A.D.W.R
}

\begin{abstract}
Betta splendens is an ornamental fish, which has high demand in the ornamental fish industry. It is a predatory fish that seems to have a high protein requirement. Natural and prepared fish diets are rich in protein. Generally fish tend to need high protein levels. In order to culture them profitably, a low cost diet suitable for their protein requirement is needed. Hence, the minimum protein required for the optimum growth of $1 \frac{1 / 2}{2} 4$ months old Betta splendens juveniles were investigated.

The minimum protein percentage required for the optimum growth of $B$. splendens was determined using five fish meal incorporated diets having different protein percentages ranging from $24.2 \%$ to $43.3 \%$. For each protein level three tanks containing 20 fish were used. Fish were fed by $5 \%$ of body weight and the amounts changed every 2 weeks after weighing them. Results were analyzed using Repeated Measurement ANOVA and the means were compared with LSD test.

According to the results the minimum protein level produced optimal growth was $33.4 \%$ and this was significantly different from the two lower levels $(p<0.05)$. The growth attained with the two protein levels above $33.4 \%$ level was similar to it. Therefore, for the diet containing $33.4 \%$ of fishmeal can be recommended as minimum protein diet for juveniles of Betta splendens.
\end{abstract}

Index Terms - Betta splendens, growth, juvenile stage, protein percentage.

\section{INTRODUCTION}

Keeping ornamental fish is a hobby, which has acquired a world wide interest. According to the F.A.O. (1999) news highlights, the export value of ornamental fish and vertebrates in 1996 was over US\$ 2000 million of which approximately $60 \%$ (US \$ 130 million) went into the economy of developing countries. Use favorite fishes in ornamental fish industry are colourful, hardy, inexpensive and conveniently sized with temperaments suited to their being kept in community aquarium [12].

The ornamental fish trade in Sri Lanka consists of fresh water as well as marine and brackish water species. While marine and brackish water aquarium fish are generally caught from the wild, the fresh water fishes are either caught from

Chathurani S.H.U., Environmental Studies Division, National Aquatic Resources Research and Development Agency (NARA), Colombo, Srilanka Rajapakshe A.D.W.R, Inland Aquatic Resources and Aquaculture Division, National Aquatic Resources Research and Development Agency (NARA), Colombo, Srilanka rivers and streams or bred in captivity.

In considering Sri Lanka's potential in the development of ornamental fish trade, it seems wise to concentrate on fresh water species. This market segment can be broken into, those that are primarily tank bred exotics ("bread and butter fishes") and those species which are indigenous to Sri Lanka. Within the trade the demand for indigenous species might be regarded as a niche market. All the "Bread and butter fish" which are mainly exotics varieties are easy to breed in captivity, and show a remarkable stability in terms of their position in the market over the years. They are guppies (Poecilia reticulata), sword tails (Xiphophorus helleri), mollies (Poecilia velifera), platies (Xiphophorus maculates), neon tetras (Thayeria boehlkei) blue gouramies, tiger barbs (Barbus tetrazona), Zebra (Brachydanio rerio), angle fish (Pterophyllum scalare) and siamese fighters (Betta splendens) [11]. So, fighter fish have significance value in fish industry.

Among the various Belontidae, Siamese fighting fish with its commercially bred for fin shape and colors, has geographical origin in South East Asia [5]. Wild living fighting fishes are smaller with a length of $2.5-3.0 \mathrm{~cm}$ compared to the domesticated ones which have length of $3-5$ $\mathrm{cm}$ [20], [21]. Their natural habitat is quit shallow fresh water ponds with muddy bottoms or flooded rice paddy fields. They can breathe oxygen from surface (due to their labyrinth organ), which enables the species to survive in low oxygen water [5]. Their fries are sexually mature after 3 months and the life time of one individual is between 2-4 years.

According to De Silva \& Anderson (1995) proper nutrition is one of the most important factors influencing the ability of cultured organisms to attain the genetic potential for growth, reproduction and longevity. The nutrient requirements vary between the species and within species between the different stages of life cycle. However, in fish farming, nutrition is critical because feed represents $40-50 \%$ of production cost. The development of species-specific diet formulations support the aquaculture industry as it expands to satisfy increasing demand for affordable safe and high quality fish and seafood products. Natural and prepared fish diets are rich in protein. Generally fish tend to need high protein levels. Food for fry and fingerlings exceed 50\% protein. The high dietary protein requirement of fish and shrimp is generally attributed to their carnivorous/omnivorous feeding habit and 
their preferential use of protein over carbohydrates as a dietary energy source [1]. In contrast to terrestrial farm animals, fish and shrimp are able to derive more metabolizable energy from the catabolism of proteins than from carbohydrates. The total amount of protein required in prepared diet is directly influenced by the amino acid composition of the diet. The diets should have a well-balanced mixture of indispensable and dispensable amino acids [14].

Dietary nutrients are essential for the construction of living tissue and as a source of energy for the life processes of fish such as digestion, absorption, growth, reproduction etc. Physiological fuel values are used to calculate the energy available in prepared diets. They typically average 5.5, 4.1 and $9.1 \mathrm{kcal} / \mathrm{g}$ for protein, carbohydrate and lipid respectively. Excess energy relative to protein content in the diet may result in high lipid deposition. Further, diets with excessive energy levels may result in decreased feed intake and cause malnutrition as fish feed to meet their energy requirements. A diet with inadequate energy content can result in reduced weight gain because the fish cannot eat enough feed to satisfy their energy requirements for growth. Properly formulated prepared feeds have a well-balanced energy to protein ratio. The ratio of protein to energy must be determined separately for each fish species to create an optimum diet.

Protein is the most costly nutrient in a formulated feed. Feed costs are the major operational expense in aquaculture typically ranging from $30 \%$ to $50 \%$ of the variable operating costs. Protein in the majority of formulated fish diets depends greatly on fishmeal, which is more costly than high quality plant-based protein sources such as soy protein. Maximizing the effective use of protein and minimizing the amount needed in feeds can substantially reduce production costs, increase farm profitability and reduce harvest of wild fish used for fishmeal. Nitrogen pollution of water also can be reduced by applying the deal protein to the formulation of fish feed. The ideal protein content in the diet should provide the exact balance, no amino acid deficiency or excess for optimum performance and maximum growth [14]. Feeds are formulated with an excess of protein usually due to two reasons is not very digestible or more has to added because specific essential amino acid requirements not known.

Fish meal is principle source of protein incorporated into many types of feeds used in aquaculture. Fish meal is the main ingredient use in fish industry [2].

Fish meal gives several benefits. It is digestible, carries large quantities of energy and high quality protein per unit weight and little carbohydrate. Addition of fish meal increases feed efficiency and growth through better food palatability and enhances nutrient uptake, digestion and absorption. High quality fish meal allow for formation of nutrient dense diets, which promote optimal growth.

The main objective or aim of the diet formulations and preparations is to utilize the knowledge of nutrient requirements, locally available feed ingredients and digestive capacity of the organisms for the development of nutritionally balanced mixture of feed stuff which will be eaten in adequate amounts to provide optimum production of cultured organisms at an acceptable cost. However, apart from that, factors like pelletability of the resulting diet, anti-nutritional factor in ingredients and diet acceptability or palatability must also be considered.

According to data collected from fish farmers (unpublished data of NARA), B. splendens has significance value in ornamental fish industry. But, ornamental fish farmers of Sri Lanka do not engaged in farming of $B$, splendens because their feeds are more expensive. Therefore, it is important to investigate a low cost feed in which fish meal is replaced by the head parts of Anchovy as a fish meal for fighter fish. Preparing such low cost feeds is important in ornamental fish industry to make the farming profitable to fish farmers. Therefore it was decided to carry out experiments to investigate the minimum protein percentage for optimum growth of juvenile Betta splendens

\section{MATERIALS AND METHODS}

In this study, the minimum protein percentage needed for the optimum growth of Betta fish was investigated with a view of introducing a low cost feed to them.

The experiments were conducted in the laboratory at Regional Research Centre of National Aquatic Resource and Research Agency (NARA) at Rekawa, Tangalle in Hambantota district of Si Lanka. The fish, Betta splendens needed for experiments were obtained by breeding the normal stocks of Regional Centre of NARA used for commercial breeding purposes. Pairs of fish were placed in glass tanks and suitable surfaces were provided for laying eggs. After the egg lay, female fish was removed from tanks to prevent them eating of their own eggs. When small fries started to swim male fish were also removed from tanks.

In the first four days food was not given as the fries have egg yolk to grow. After that, boiled egg yolk dissolved in water was provided as the feed. After ten days, they were fed with micro worms cultured in bread and after fourteen days they were fed with Artemia and mosquito larvae. About one and a half month old fish were fed with live feeds. After that artificial feeds were given. Therefore, one and half months old fishes were taken for feeding trials.

During the experimental period, fish were maintained under normal environmental conditions; the three most important parameters were maintained within the ranges; $25^{\circ} \mathrm{C}-29^{\circ} \mathrm{C}$ for temperature, $6.9-8.0$ for $\mathrm{pH}$ and $5-7 \mathrm{mg} / \mathrm{l}$ for

dissolve

oxygen.

\section{Diet preparation}

As the range of protein requirement of fish vary from $25 \%$ to $50 \%$, it was decided to prepare test diets with protein percentages $25,30,35,40,45$ and 50 to evaluate the growth performance.

Diets for this trial were prepared using fish meal as the sole protein provider. In order to adjust the protein level, rice bran was used as it has very low protein content. Wheat flour was used as the binder. In addition, fish oil, vitamin and mineral mixture were incorporated in normal amounts.

The nutrient contents in the feed ingredients were obtained 
using the FAO manual [15], [16]. These values for the used ingredients are given in table 1 .

The Pearson square method was used to calculate the amount of fishmeal, rice bran and wheat flour needed to be mixed to obtain the necessary protein percentage. How the Pearson's Square method calculations were done is given in the Annex 1. The percentages of the ingredients used for preparing each diet for required protein percentages are given in the Table 2

The ingredients were ground using a blender. After grinding each ingredient was sieved using the same sieve to obtain uniform particles. Then the amounts require for each diet were weighed by using an electronic balance. Next the measured fish meal, rice barn and wheat flour for each diet were mixed separately and these mixtures were heated by steam. After that mixtures were allowed to cool. Fish oil, Vitamin and mineral mixture were then added to each diet. Next, the diets were pelleted using the pelleting instrument. Finally, these pelleted feeds were dried in an oven at $35^{\circ} \mathrm{C}$ temperature. Finally dried diets were separately stored in packets.

Since the actual percentages of protein in diets may deviate from the set value the feeds were analyzed to investigate the actual protein content using the Kjeldhal method. Nitrogen contents in diets were measured using the Kjeldhal apparatus model UDK 132, semi-automatic steam distilling unit of Velp Scientifica Company, at the Chemistry Lab of NARA, Mattakkuliya.

\section{Experimental design and setting up of experiment}

In order to investigate the growth performance of diets, it was decided to test the five diets in three replicates. (The first diet was not tested as the actual protein percentage of it was less than $20 \%$.) Fifteen $60 \mathrm{~cm}$ x $30 \mathrm{~cm}$ x $30 \mathrm{~cm}$ glass tanks were used for the experiment (five diets in three replicates). Water levels were maintained at $15 \mathrm{~cm}$ in height. Tanks were named as F1a, F1b, F1c, F2a, F2b, F2c, ........... F5a, F5b, F5c.

One and half month older Betta splendens fries who had reached $1 \mathrm{~cm}-2 \mathrm{~cm}$ in their total lengths were used for the experiment. Fishes were pooled and 300 were selected for the trial. Without considering the length variation 20 fries were placed in each tank. An extra tank was maintained for each diet to replace fish dying during the experimental period. This study was conducted during 10 November 2009 to 02 February 2010. During this experiment normal environmental conditions were maintained (not use aerators because fighter fish can survive in low oxygen). Tanks were cleaned daily by siphoning out $2 / 3$ of water with feces and remaining feeds. Fishes were fed with $5 \%$ weight of diet of their body weight [4].

\section{Measuring of water quality}

In order to see whether the fish have been kept in suitable water quality conditions, the water quality condition maintained throughout the experimental period was checked by measuring water quality parameters indicated below.
Water temperature and $\mathrm{pH}$ of water just below the surface was recorded daily by using a battery operated Cyberscan $\mathrm{pH}$ 11 meter. Also the battery operated, SM 600 DO meter used for the analysis of dissolved oxygen. Ammonia nitrogen, Nitrate nitrogen, Nitrite nitrogen and Alkalinity tests were performed according to Standard Methods for the Examination of Water and Waste Water (1998).

Feeding trial and measurement of growth performance

During this time period weight of the fish were measured at two week interval by using an electronic balance. Random samples of fish consisting of ten individuals from each tank were measured to the nearest $0.01 \mathrm{~g}$. As fishes were fed according to their body weights, at the end of every two weeks the feeding weight of their diets were adjusted according to the measured body weights.

\section{Analysis of data and finding out the minimum protein percentage for optimum growth}

At the end of each two week interval, the weights gained by fish fed with 5 different protein levels were analyzed using one-way ANOVA to find out whether the weight gains are significantly different from each other and multiple comparison tests were performed whenever necessary to find out which diet/s is/are different from the others.

A graph was plotted to show the mean weight gain with the 5 protein percentages against the time.

\section{RESULTS AND ANALYSIS}

\section{Diet preparation}

The Pearson's equation was used to determine the amounts of ingredients that should be mixed to attain the necessary protein amounts of the diets. However, the chemical analysis of diets for their protein contents using Kjeldhal method revealed that the actual protein content deviated from the targeted amounts. Results of the chemical analysis of diets with the targeted amounts are given in Table 3.

It is evident from the Table 3 that the actual protein percentages of prepared diets were about $5.6 \%-6.7 \%$ lower than targeted protein percentages. Here after, the actual protein percentage values were considered as the correct protein contents of the diets. Since protein requirements of smaller fishes are high, the diet with the protein content 19.4 $\%$ was not used for the experiment.

\section{Water quality parameters}

During the experimental period three water quality parameters; water temperature, $\mathrm{pH}$ and dissolved oxygen (DO) were measured daily in every tank. The alkalinity, ammonia and nitrate were measured once in two weeks in every tank. The results are shown in Table 4.

Throughout the experiment ammonia and nitrate levels were almost close to zero due to the daily cleaning of the tanks. Even without aeration, oxygen content of 5-6 mg/l could be achieved. It is evident from these data that the fish in experimental tanks have been maintained in suitable water quality conditions and there has not been much difference between experimental tanks. Therefore, the effect of water quality parameters on growth has been minimal in this 
experiment.

\section{Growth performance of fish fed with five different protein levels}

In this experiment, fish were fed with diets having different protein contents and the growth of the fish was measured in two week intervals. The mean total weights gained by the fish at each two week interval with the 5 different diets are given in Table 5. Figure 1 shows the weight gain against the time while Figure 2 shows the weight gain against the protein level. It is evident that the protein percentages from these two graphs that the protein levels $33.4 \%, 38.5 \%$ and $43.3 \%$ causes almost equal weight gains.

The statistical test, Repeated Measurement ANOVA, was performed to find out whether the five different protein levels gave significant differences between the protein levels. The difference was proved with a $\mathrm{P}=0.0001$ value. The Least Significance Difference Test (LSD) performed showed that performance of protein levels $24.3 \%$ and $29.2 \%$ are similar and different from other 3 protein levels while protein levels $33.4 \%, 38.5 \%$ and $43.3 \%$ are similar and they are different from the lower two protein levels. The result of the statistical test is given in the Annex IV.

Therefore, the protein level $33.4 \%$ seems the minimum protein level which gives optimum growth of B. splendens.

\section{DISCUSSION}

Betta splendens is a resource with a high market value. This resource has not been harnessed for the export market of Sri Lanka yet. The main reason is the high expenditure on high protein diets, as they are predatory fish that must be kept in high protein diet [5]. Protein is the most expensive part of the diet. If we use more protein in fish industry, especially fish meal it is not cost effective [14]. Therefore, it is important to know the minimum protein percentage required for optimum growth of Betta splendens and replace at least a part of it with a low cost plant protein.

James \& Kunchitham (2003) investigated the minimum protein percentage giving optimum growth of Betta splendens adults as $35 \%$. Since the dietary protein requirement vary with the life stage of fish, it was decided to find out the minimum protein requirement of $1 \frac{1 / 2}{2}-4$ months old fish, whom we are dealing with in this experiment. In order to investigate this, five diets were prepared by using anchovy as main fish meal source and changing their percentages in the diets. The resulted protein value was lower than the targeted value, most probably because the nutrition values of ingredients were taken from the literature due to limited laboratory facilities for analyses. However, after preparing feeds actual protein amounts were found out and these values were used for analysis.

When investigating the minimum protein required for optimum growth, resulted growth value showed the significant difference $(\mathrm{P} \leq 0.05)$ between the diets. Protein levels above $33.4 \%$ gave similar growth rates. Therefore, the protein content $33.4 \%$ can be considered as the minimum protein level giving optimum growth. This shows that there is no difference between the minimum dietary requirement of proteins in the adult and juvenile stages. At higher protein levels usually the growth rate should become lower as energy is utilized for the de-amination process. Since we investigated up to the protein level $43.3 \%$ which may be tolerable by a carnivore, the de-amination energy loss may be occurring in levels beyond that.

\section{CONCLUTION}

Diet with $33.4 \%$ of protein meal can be recommended for the juvenile stage of B. splendens.

\section{ACKNOWLEDGEMENT}

Authors wish to acknowledge National Aquatic Resources research and development Agency for providing funds for success this project.

\section{REFERENCES}

[1] Cowey, C.B., Pope, J.A., Adron, J.W. \& Blair, A. (1972) Studies on the nutrition of marine flatfish. The protein requirement of plaice (Pleuronectes platessa). Br. J. Nutr. 28, 447-456.

[2] De Silva, S.S \& Anderson, T.A. (1995) Fish nutrition and aquaculture. Chapman and Hall. London, UK

[3] Erdal, Y. \& Ercument, G. (2006), Effects of Alternative dietary Lipid sources(Soy-acid oil and yellow grease) on Growth and Hepatic Lipidosis of common carp(cyprinus carpio) fingerlings .A preliminary study, Turkish journal of fisheries and Aquatic sciences Vol.6: pp 37-42.

[4] Edwin, H. \& Menghe, H.L (2007), Effects of fish size and feeding frequency on channel catfish production.

[5] Forbeg, A (2003) The Siamese fighting fish (Betta splendens)-An alternative fish species to use in evaluating the impact of endocrine disrupting chemicals with focus on aggressive performance, Field study 87, Uppsala University, Sweden.

[6] Francis, R.F (2002), Institute of food and agricultural Science, University of Florida.

[7] Garrick, T.S., Mathew E.P., James F.G \& Russell J.B (2005), Variable intake, compensatory growth efficiency in fish. Models and mechanisms, Ecological society of America 86 (6), pp1452-1462.

[8] Gropp, J, Koops, H., Tiews, K. \& Beck, H., (1979). Replacement of fishmeal in trout feeds by other feedstuff. In: T.V.R.Pillay and W.A. Dill (Editors), Advances in Aquaculture, Fishing news (Books) Surrey, pp. 596-601.

[9] Guptha, S.K., \& Guptha, P.C (2006), Genaral and Applied Ischylolgy.S and Chand and company Ltd.Ram Nagar, New delhi.

[10] Hartley, P.H.T (1948), Food and feeding relationships in a community of fresh water fishes,Journal of Animal ecology.vol.17,pp1-14

[11] Hettiarachchi, M. \& Dassanayaka, M.P.S (2000) Growth performance and colour enhancement of guppy ,Poecilia reticulate when fed with locally formulated pigment included diets, Sri Lanka journal of aquaculture ,Sci.5(2000):39-46

[12] Jonklass, R.L (1982), Ornamental fish foods and feeding techniques, NARA technical paper No.3, pp1-12

[13] Lovell, T (1989), Nutrition and feeding fish. Van Nostrand Reinhold Publishers, New York, USA

[14] Miles, R.D. \& Chapman, F.A (2007), The concept of ideal protein in formulation of Aquaculture feeds, FA 145, University of florida

[15] National research council, (1983). Nutrient requirement of fish, National academy press. Washington DC, USA

[16] National research council, (1983), Nutrient requirement of warm water fishes and shellfishes, National academy press. Washington DC, USA

[17] Oscar, J.C., Kinnucan, H \& Upton, H (1991), Optimal control of fish growth, American journal of Agricultural economics,vol.73,pp174-183

[18] Pillay, T.V.R ed: (2001), Aquaculture principles and practices, Blackwell science L.t.d

[19] Radha, C.D \& Archana, S (2003), Ornamental fish trade in India Fishing chimes.vol.23.No2,pp16-18

[20] Raja, J. \& Sampath, K (2004), Effect of water hardness on growth and reproductive potential in Xiphophorus Helleri and Betta splendens „Journal of Aquaculture .Trop,19(4)(2004).pp.255-266 
[21] Raja, J. \& Sampath, K (2003), Effect of animal protein diets on growth and fecundity in ornamental fish,Betta splendens, The Israeil Journal of aquaculture,_vol 55,pp39-52

[22] Robinson, E.H \& Manning, B.B (2001), A Practical guide to nutrition, feed, and feeding, 2nd revision. Mississippi Agricultural and Forestry Experiment Station Bulletin No. 1113. Mississippi State, Mississippi.

[23] Santhanam, R., Sukumar, N \& Natrajan, P (1990). A manual of fresh water aquaculture, Oxford and IBH publishing co.pvt limited.

Annex -1

- Calculations for the amount of feed ingredients used in diets (using Pearson square)
[24] Stephen, B.B (1993), The effect of thermal fronts on fish growth :A biogenetics Evaluation of food and temperature ,Estuaries,vol-16,no-1,pp142-159

[25] Steven, C. \& Helfrich H.A (2009), Understanding fish nutrition feeds and feeding, pp 256-420

Protein content of ingredient ' $A$ '

Proportion of ingredient 'A' Require

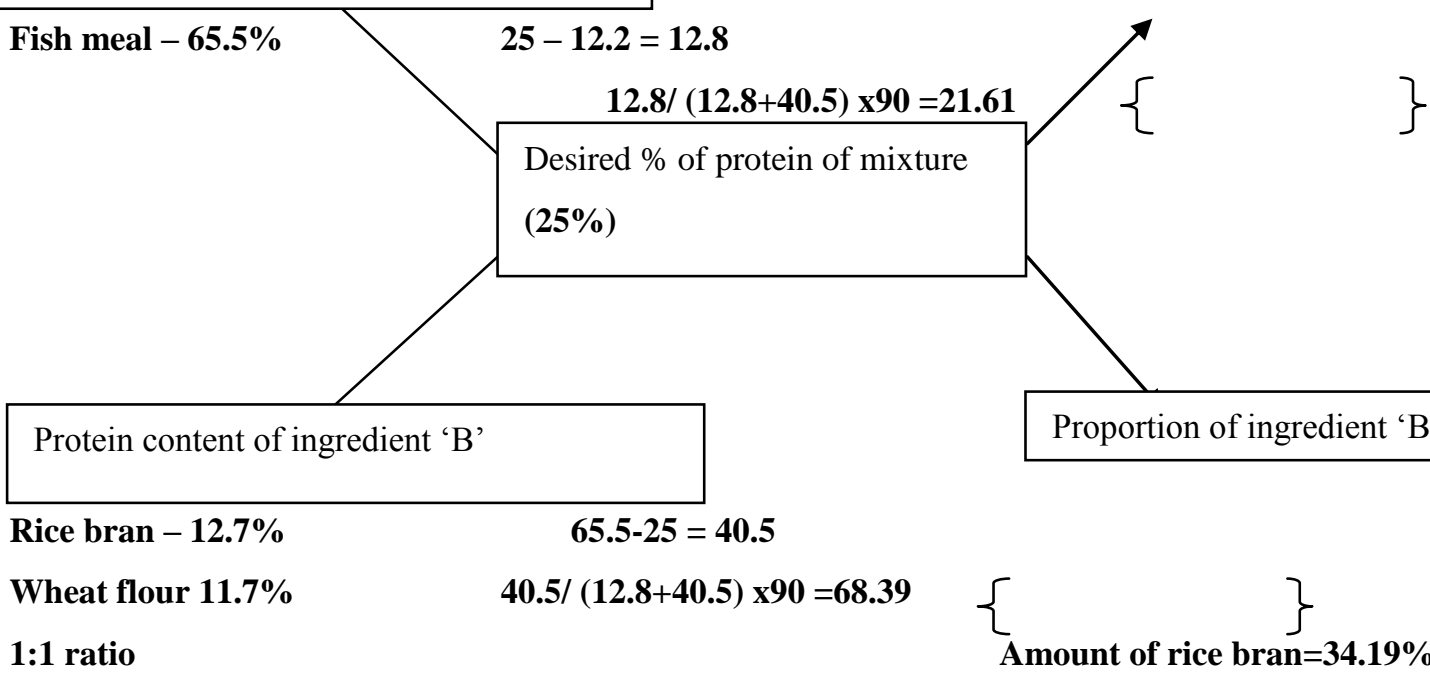

$\underline{12.7+11.7}=12.2$

Amount of wheat flour $=34.19 \%$

2

List of tables

Table 1: The nutrient contents of the main ingredients which were used to prepare diets

\begin{tabular}{|c|c|c|c|c|c|c|}
\hline Ingredients & $\begin{array}{l}\text { International } \\
\text { feed number }\end{array}$ & $\begin{array}{l}\text { Dry } \\
\text { matter\% }\end{array}$ & $\begin{array}{l}\text { Crude } \\
\text { protein }\end{array}$ & Arginine & Glycine & Cystein \\
\hline $\begin{array}{l}\text { Fish meal (Anchoy) meal } \\
\text { mech extr }\end{array}$ & $5-01-969$ & 92.0 & 65.5 & 3.8 & 3.6 & 0.6 \\
\hline Rice bran & $4-03-928$ & 91.0 & 12.7 & 0.7 & 0.8 & 0.1 \\
\hline Wheat flour & 4-05-199 & 88.0 & 11.7 & 0.4 & 0.4 & 0.3 \\
\hline $\begin{array}{l}\text { Soy bean (Glycine max) } \\
\text { Seeds heat processed } \\
\text { Seeds meal mech. extr } \\
\text { Seeds meal solv. extr }\end{array}$ & $\begin{array}{l}5-04-597 \\
5-04-600 \\
5-04-604 \\
\end{array}$ & $\begin{array}{l}90.0 \\
90.0 \\
90.0 \\
\end{array}$ & $\begin{array}{l}38.0 \\
42.9 \\
44.8\end{array}$ & $\begin{array}{l}2.8 \\
3.1 \\
3.0\end{array}$ & $\begin{array}{l}2.0 \\
2.4 \\
1.8\end{array}$ & $\begin{array}{l}0.5 \\
0.5 \\
0.7\end{array}$ \\
\hline $\begin{array}{l}\text { Mung bean (Taken from } \\
\text { FAO manual) }\end{array}$ & ----------- & 88.1 & 24.4 & $\begin{array}{l}\text { Not } \\
\text { given }\end{array}$ & $\begin{array}{l}\text { Not } \\
\text { given }\end{array}$ & 0.6 \\
\hline
\end{tabular}

Table 2: Amounts of feed ingredients used to prepare $100 \mathrm{~g}$ of diet

\begin{tabular}{|c|l|l|l|l|l|l|}
\hline $\begin{array}{c}\text { Percentage of } \\
\begin{array}{c}\text { protein in } \\
\text { diet }\end{array}\end{array}$ & $\begin{array}{l}25 \% \\
\text { Weight }(\mathrm{g})\end{array}$ & $\begin{array}{l}30 \% \\
\text { Weight }(\mathrm{g})\end{array}$ & $\begin{array}{l}35 \% \\
\text { Weight }(\mathrm{g})\end{array}$ & $\begin{array}{l}40 \% \\
\text { Weight }(\mathrm{g})\end{array}$ & $\begin{array}{l}45 \% \\
\text { Weight }(\mathrm{g})\end{array}$ & $\begin{array}{l}50 \% \\
\text { Weight }(\mathrm{g})\end{array}$ \\
\cline { 2 - 7 } & & & & & & \\
\hline Fish meal & 21.6 & 30.0 & 38.5 & 47.0 & 53.4 & 63.8 \\
\hline Wheat flour & 34.2 & 30.0 & 27.7 & 21.5 & 17.3 & 13.0 \\
\hline Rice bran & 34.2 & 30.0 & 27.7 & 21.5 & 17.3 & 13.0 \\
\hline
\end{tabular}


Investigation of Minimum Protein Percentage Required for Optimum Growth of Siamese Fighter Fish, Betta Splendens (Regan, 1950) in Juvenile Stage

\begin{tabular}{|l|l|l|l|l|l|l|}
\hline Fish oil & 8.0 & 8.0 & 8.0 & 8.0 & 8.0 & 8.0 \\
\hline Vitamin & 1.0 & 1.0 & 1.0 & 1.0 & 1.0 & 1.0 \\
\hline Minerals & 1.0 & 1.0 & 1.0 & 1.0 & 1.0 & 1.0 \\
\hline
\end{tabular}

Table 3: Differences of the targeted protein percentage and actual protein percentages of the diets

\begin{tabular}{|c|c|c|c|c|c|c|c|c|}
\hline $\begin{array}{l}\text { Feed } \\
\text { number }\end{array}$ & Sample & $\begin{array}{l}\text { Sample } \\
\text { weight } \\
\text { (g) }\end{array}$ & $\begin{array}{l}\text { Vol. } \\
\text { of } \\
\mathrm{HCl} \\
(\mathrm{ml})\end{array}$ & $\begin{array}{l}\text { Total } \\
\text { nitro } \\
\text { gen } \\
\% \\
(\mathrm{~N})\end{array}$ & $\begin{array}{l}\text { Actual } \\
\text { percentage of } \\
\text { protein in } \\
\text { diets } \\
(\mathrm{N} \times 6.25)\end{array}$ & $\begin{array}{l}\text { Actual } \\
\text { percentage of } \\
\text { protein in diets } \\
\text { Mean } \pm \text { SD } \\
n=3\end{array}$ & $\begin{array}{l}\text { Targeted } \\
\text { protein } \\
\text { percentage }\end{array}$ & $\begin{array}{l}\% \\
\text { deviation }\end{array}$ \\
\hline \multirow[t]{3}{*}{$\mathrm{F} 1$} & $\mathrm{~S} 1$ & 2.0041 & 23.7 & 3.13 & 19.58 & \multirow{3}{*}{$\begin{array}{l}19.41 \\
\pm 0.36\end{array}$} & \multirow{3}{*}{25} & \multirow{3}{*}{5.6} \\
\hline & $\mathrm{S} 2$ & 2.0039 & 23.8 & 3.14 & 19.67 & & & \\
\hline & S3 & 2.1042 & 24.2 & 3.04 & 19.00 & & & \\
\hline \multirow[t]{3}{*}{$\mathrm{F} 2$} & S1 & 2.0239 & 29.6 & 3.88 & 24.24 & \multirow{3}{*}{$\begin{array}{l}24.27 \\
\pm 0.12\end{array}$} & \multirow{3}{*}{30} & \multirow{3}{*}{5.7} \\
\hline & $\mathrm{S} 2$ & 2.0653 & 30.1 & 3.86 & 24.16 & & & \\
\hline & S3 & 2.2008 & 32.4 & 3.90 & 24.41 & & & \\
\hline \multirow[t]{3}{*}{ F3 } & S1 & 2.0029 & 35.7 & 4.73 & 29.56 & \multirow{3}{*}{$\begin{array}{l}29.21 \\
\pm 0.57\end{array}$} & \multirow{3}{*}{35} & \multirow{3}{*}{5.8} \\
\hline & $\mathrm{S} 2$ & 2.1026 & 36.2 & 4.56 & 28.55 & & & \\
\hline & S3 & 2.0453 & 36.4 & 4.72 & 29.52 & & & \\
\hline \multirow[t]{3}{*}{$\mathrm{F} 4$} & S1 & 2.0102 & 40.6 & 5.36 & 33.51 & \multirow{3}{*}{$\begin{array}{l}33.45 \\
\pm 0.32\end{array}$} & \multirow{3}{*}{40} & \multirow{3}{*}{6.6} \\
\hline & $\mathrm{S} 2$ & 2.0234 & 41.2 & 5.40 & 33.75 & & & \\
\hline & S3 & 2.1203 & 42.3 & 5.29 & 33.10 & & & \\
\hline \multirow[t]{3}{*}{ F5 } & S1 & 2.0046 & 46.6 & 6.19 & 38.66 & \multirow{3}{*}{$\begin{array}{l}38.48 \\
\pm 0.63 \\
\end{array}$} & \multirow{3}{*}{45} & \multirow{3}{*}{6.5} \\
\hline & $\mathrm{S} 2$ & 2.0036 & 47.1 & 6.24 & 39.01 & & & \\
\hline & S3 & 2.1006 & 47.9 & 6.04 & 37.77 & & & \\
\hline \multirow[t]{3}{*}{ F6 } & S1 & 2.0014 & 50.8 & 6.75 & 42.21 & \multirow{3}{*}{$\begin{array}{l}43.27 \\
\pm 0.94\end{array}$} & \multirow{3}{*}{50} & \multirow{3}{*}{6.7} \\
\hline & $\mathrm{S} 2$ & 2.0102 & 52.8 & 6.97 & 43.60 & & & \\
\hline & S3 & 2.0142 & 53.4 & 7.04 & 44.01 & & & \\
\hline
\end{tabular}

Table 4: Water quality data of the experiment that investigated the effect of dietary protein level on fish growth

\begin{tabular}{|c|c|c|c|c|c|c|}
\hline Tank number & $\begin{array}{l}\text { Water } \\
\text { temperature/ } \\
\text { C }\end{array}$ & $\mathrm{pH}$ & $\begin{array}{ll}\mathrm{DO} & \mathrm{mg} / \mathrm{l} \\
(\mathrm{ppm}) & \end{array}$ & Ammonia (mg/l) & Nitrates $(\mathrm{mg} / \mathrm{l})$ & Alkalinity (mg/L) \\
\hline F1 & $27.4 \pm 0.4$ & $7.6 \pm 0.3$ & $5.3 \pm 0.4$ & $0.0003 \pm 0.0005$ & $0.0006 \pm 0.0002$ & $198 \pm 0.0$ \\
\hline $\mathrm{F} 2$ & $27.5 \pm 0.5$ & $7.4 \pm 0.3$ & $5.4 \pm 1.1$ & $0.0005 \pm 0.000$ & $0.0009 \pm 0.000$ & $186 \pm 0.0$ \\
\hline F3 & $27.6 \pm 0.5$ & $7.5 \pm 0.2$ & $5.3 \pm 0.4$ & $0.0002 \pm 0.0005$ & $0.008 \pm 0.0004$ & $178 \pm 0.4$ \\
\hline F4 & $27.5 \pm 0.4$ & $7.5 \pm 0.4$ & $5.1 \pm 1.0$ & $0.0001 \pm 0.0003$ & $0.0008 \pm 0.0002$ & $188 \pm 0.1$ \\
\hline F5 & $27.5 \pm 0.4$ & $7.5 \pm 0.1$ & $5.4 \pm 0.3$ & $0.0001 \pm 0.0000$ & $0.0009 \pm 0.0002$ & $185 \pm 0.2$ \\
\hline $\begin{array}{l}\text { Acceptable } \\
\text { levels } \\
\text { (Sandford, } \\
1999 \text { ) }\end{array}$ & $25^{\circ} \mathrm{C}-29^{\circ} \mathrm{C}$ & $6.9-8.0$ & $5-8$ & 0.5 & 0.1 & - \\
\hline
\end{tabular}


Table 5: Growth performance fishes when fed with different protein percentages

\begin{tabular}{|c|c|c|c|c|c|c|c|c|}
\hline & Weight of the & fishes $(\mathrm{g}), \mathrm{Me}$ & $1 \pm \mathrm{SD}, \mathrm{n}=30$ & & & & & $\begin{array}{l}\text { Overall } \\
\text { Mean } \\
\mathrm{N}=180\end{array}$ \\
\hline $\begin{array}{l}\text { protein } \\
\text { percentage }\end{array}$ & 0 days & 14 days & 28days & 42 days & 56 days & 70 days & 84 days & $P=0.0001$ \\
\hline 24.3 & $0.023 \pm 0.010$ & $0.035 \pm 0.005$ & $0.079 \pm 0.004$ & $0.106 \pm 0.005$ & $0.158 \pm 0.002$ & $0.196 \pm 0.017$ & $0.265 \pm 0.002$ & $0.14067 \mathrm{a}$ \\
\hline 29.2 & $0.023 \pm 0.010$ & $0.045 \pm 0.005$ & $0.082 \pm 0.001$ & $0.114 \pm 0.001$ & $0.183 \pm 0.006$ & $0.226 \pm 0.005$ & $0.319 \pm 0.002$ & $0.16194 \mathrm{a}$ \\
\hline 33.4 & $0.023 \pm 0.010$ & $0.053 \pm 0.001$ & $0.122 \pm 0.001$ & $0.131 \pm 0.004$ & $0.232 \pm 0.004$ & $0.32 \pm 0.004$ & $0.437 \pm 0.003$ & $0.21494 \mathrm{~b}$ \\
\hline 38.5 & $0.023 \pm 0.010$ & $0.057 \pm 0.005$ & $0.124 \pm 0.001$ & $0.136 \pm 0.003$ & $0.24 \pm 0.007$ & $0.325 \pm 0.007$ & $0.442 \pm 0.003$ & $0.22089 \mathrm{~b}$ \\
\hline 43.3 & $0.023 \pm 0.010$ & $0.057 \pm 0.001$ & $0.125 \pm 0.002$ & $0.138 \pm 0.001$ & $0.245 \pm 0.003$ & $0.327 \pm 0.005$ & $0.455 \pm 0.002$ & $0.22478 \mathrm{~b}$ \\
\hline
\end{tabular}

List of Figures

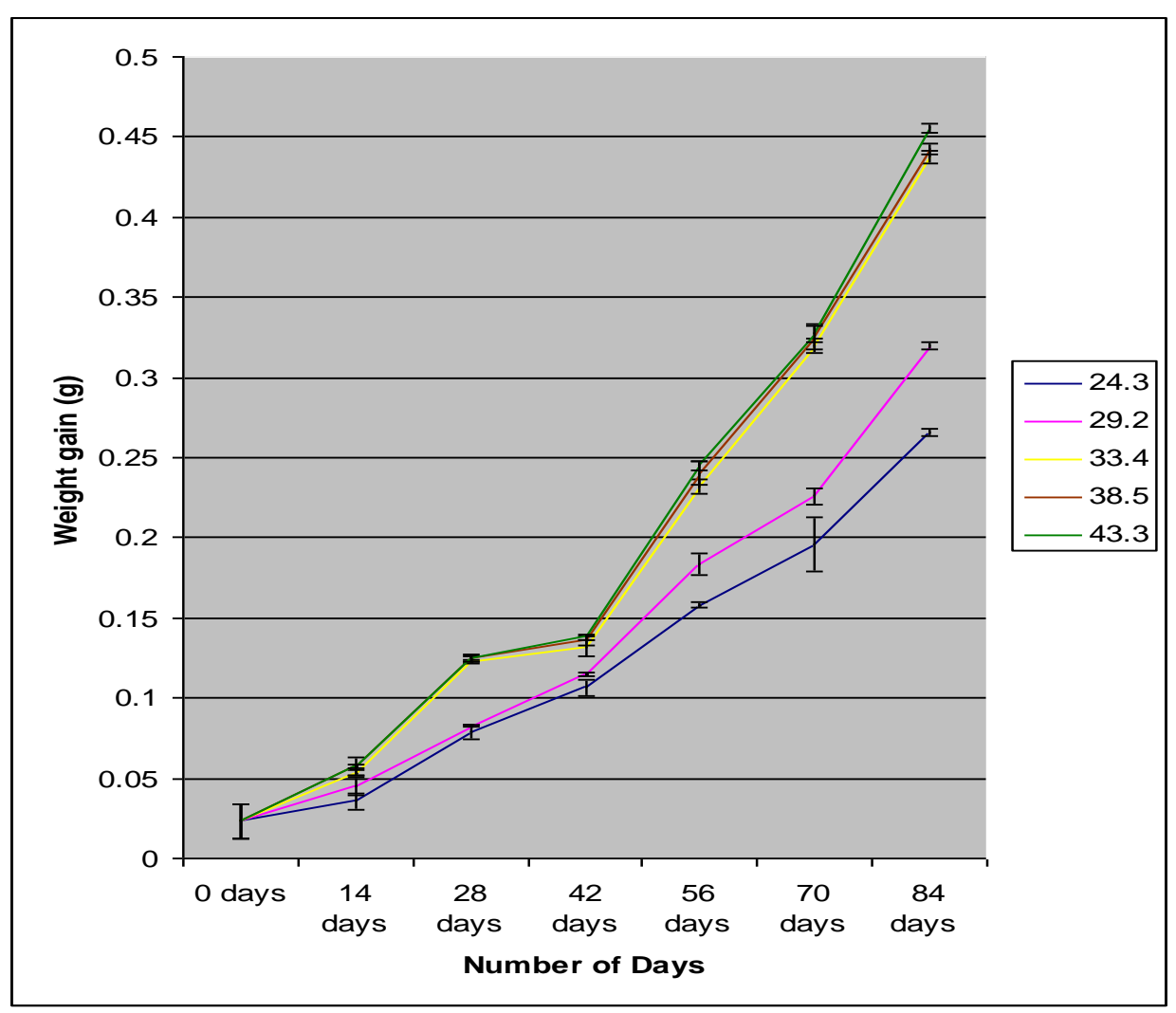

Figure 1: Growth performance of fishes during 85 days when feed with diets having different protein percentages 
Investigation of Minimum Protein Percentage Required for Optimum Growth of Siamese Fighter Fish, Betta Splendens (Regan, 1950) in Juvenile Stage

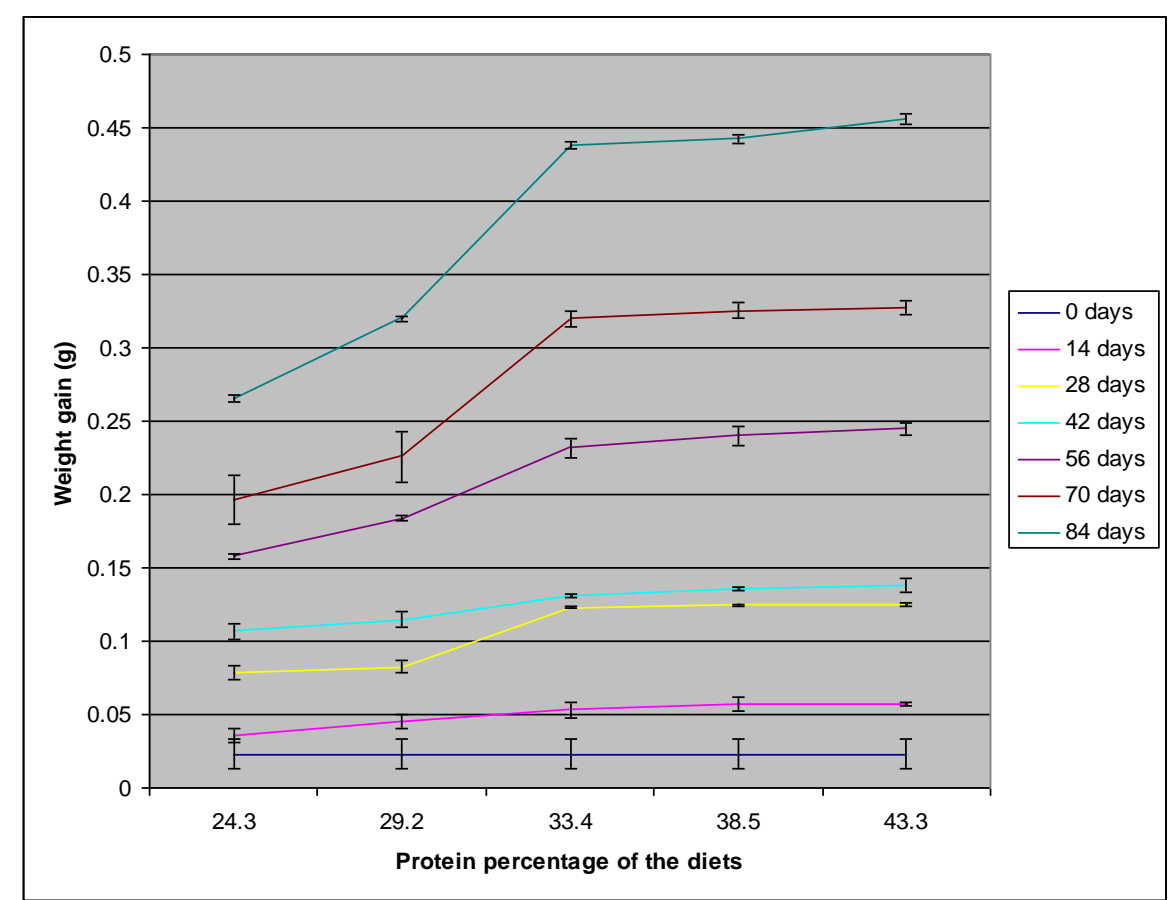

Figure 2: Growth of the fishes with time when fed with different protein diets 